\title{
In honor of Professor Robert P. Hanzlik on the occasion of his retirement
}

\author{
Siming L. Wang ${ }^{1} \cdot$ Longqin $\mathrm{Hu}^{2} \cdot$ Binghe Wang ${ }^{3}$
}

Published online: 19 June 2020

(c) Springer Science+Business Media, LLC, part of Springer Nature 2020

This issue of Medicinal Chemistry Research is dedicated to Dr Robert P. Hanzlik, Professor and Chair, Department of Medicinal Chemistry, the University of Kansas (KU), on the occasion of his retirement after 49 years of loyal and dedicated service to the University of Kansas and to the biomedical sciences.

Professor Hanzlik was born in a working-class neighborhood of Chicago in 1943. He attended local schools, graduating from Harrison Technical High School in 1961. He went on to Southern Illinois University at Carbondale where he double-majored in Chemistry and Zoology. After graduating with a BA degree in 1966, he received a NSF Graduate Fellowship and went to Stanford University to study organic chemistry and enzyme mechanisms under the direction of Professors Eugene E. van Tamelen and Raymond B. Clayton. His research was done on the then-hot topic of enzyme-mediated cyclization of squalene epoxide to lanosterol. After receiving his Ph.D. in 1970, he worked for one year as a NATO-NSF postdoctoral fellow with Professor Jack Lewis at Cambridge University studying biomimetic oxygenase models, and then joined the faculty of the Department of Medicinal Chemistry at the University of Kansas.

Siming L. Wang

swang@gsu.edu

1 Department of Chemistry, Georgia State University, Atlanta, Georgia 30303, USA

2 Department of Medicinal Chemistry, Ernest Mario School of Pharmacy, Rutgers University New Brunswick, Piscataway, New Jersey 08854, USA

3 Department of Chemistry and Center for Diagnostics and Therapeutics, Georgia State University, Atlanta, Georgia 30303, USA

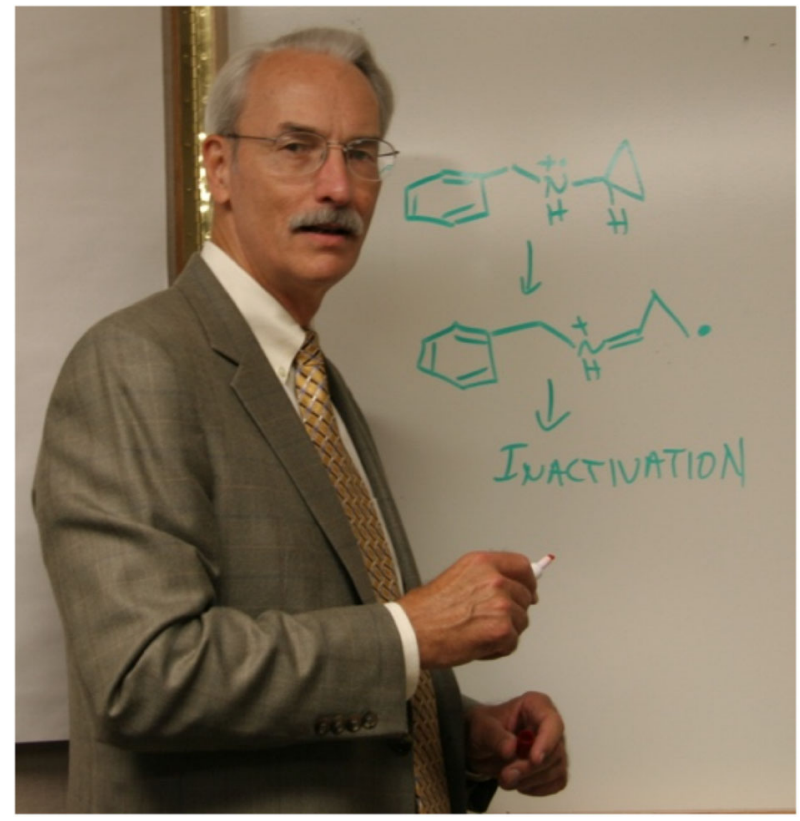

Professor Hanzlik's research has embraced organic chemistry, enzyme inhibition, drug metabolism and toxicology. His interest in the latter is best described in his own words: "I look at simple chemicals that one might encounter in industry, in agriculture, in the environment, or even as drugs, and I ask the question-how do they cause toxic effects on cells?" His research has employed approaches ranging from physical organic chemistry to the use of mass spectrometry-based proteomics to characterize reactive metabolites from bromobenzene and thiobenzamide and identify their protein targets to help elucidate the contribution of covalent protein binding to toxicity. He also conducted pioneering research on electrophilic inhibitors of cysteine proteases, studied mechanisms of aliphatic and aromatic hydroxylation, discovered cyclopropylamines as suicide substrates for cytochrome P450s, and investigated the biotransformation and toxicity of transition metal organometallics such as ferrocene. Professor Hanzlik's research was supported by many sources including the $\mathrm{NIH}$, 
the University of Kansas, NSF-NATO, The American Lung Association, Research Corporation, Ethyl Corporation, The American Heart Association, Merck Research Laboratories, Eli Lilly, and Pfizer. In his long career he has authored or co-authored 160 peer-reviewed research publications, 14 reviews, and a textbook (Inorganic Aspects of Biological and Organic Chemistry).

Professor Hanzlik became a leading figure in his field and was often called upon for leadership and service roles, including serving as the President of the International Society for the Study of Xenobiotics $(1996,1997)$ and on numerous review panels at the NIH and other agencies. Professor Hanzlik is a recipient of the Sato Memorial International Award from the Foundation for Education in Science and the Pharmaceutical Society of Japan, and the Olin Petefish Research Award in the Basic Sciences from the University of Kansas, among other honors. He has been a long-term member of the ACS, RSC, AAAS, SOT, and ISSX, and was elected a Fellow of AAAS in 1994.

Beyond the impact of his research work, Professor Hanzlik personally trained over 60 graduate students and postdoctoral fellows in his lab and influenced an even larger number of trainees who went through the KU Med Chem program and on to very successful careers. The three of us joined KU as graduate students in medicinal chemistry while Professor Hanzlik was the Director of Graduate Studies. Witnessing his passion for science, rigor in conducting research, diligence in mentoring students, and devotion to scholarship was a powerful experience that has left a lasting impression and influence on us. When Professor Hanzlik assumed the position of department chair in 2017, the KU Med Chem program was going through a re-building phase. He was instrumental in bringing in a group of outstanding scientists to put the department on a strong upward trajectory.

Professor Hanzlik's efforts extended far beyond the Department of Medicinal Chemistry. From 2002 until 2018, he directed an NIH Center of Biomedical Research Excellence in Protein Structure and Function, one of the first such programs in the state. COBRE-PSF had two missions: to pursue basic health-related research on proteins, and to recruit, support and mentor outstanding junior faculty in the biosciences at universities throughout the state of Kansas. The impact of the COBRE center on the career development of multiple junior faculty members throughout the state has been profound, and the four Core laboratories that Professor Hanzlik established at KU (Mass Spectrometry, Protein Production, Protein X-ray Crystallography, and High-field Bio-NMR) will continue to serve researchers at $\mathrm{KU}$ for years to come.

On a personal side, Professor Hanzlik is a devoted husband to his wife Lois (of 55 years and counting) and an avid sportsperson. He loves hiking and windsurfing, and is a founding member of the KU Mad Dogs noontime running group (as in "Mad dogs and Englishmen go out in the noonday sun"). This is another case of Professor Hanzlik leading by example by balancing a busy schedule with activities to stay healthy!

On behalf of ourselves and all the contributors to this issue, it is a privilege to honor Professor Hanzlik for his career in science and his service to its practitioners. We wish Bob and Lois a happy, healthy, and active retirement together.

Siming L. Wang Director of Mass Spectrometry Facility Georgia State University

Longqin $\mathrm{Hu}$

Professor and Chair Department of Medicinal Chemistry Ernest Mario School of Pharmacy Rutgers University New Brunswick

Binghe Wang Regents' Professor and GRA Eminent Scholar Director, Center for Diagnostics and Therapeutics Georgia State University 